the subject, date, production unit, technical characteristics, language used, etc. Four cross-indexes locate the material.

Eighty per cent of the films listed were made in French-speaking countries: the book itself appears only in French and there are no plans to bring out other language editions. The films deal with such subjects as religion, news, technology, and the arts.

\title{
A Note on Some Recent Bibliographies of African Literature
}

THERE have been several recent attempts to compile bibliographies of works of African writers published in Africa and elsewhere. One such attempt, "Bibliographie africaine et malgache', appeared in 1963 in Revue de litterature comparée but lists only the works of French African writers published in French. Others have been produced by the Deutsche Afrika-Gesellschaft in Bonn (Schöne Schriften aus Afrika, 1962) and the American Society of African Culture in New York (Some Modern African Writers, 1964); both these contain biographical data but are incomplete as attempts to enumerate all the works of African writers.

At the Dakar Conference on African Literature and the University Curriculum in 1963 Janheinz Jahn, the German literary historian, announced that he was preparing a bibliography to include data on all the works of African and American negro writers, and the furthering of this project was among the resolutions passed by the conference. This appeared in 1965 (Die neoafrikanische Literatur: Gesamtbibliographie von den Anfängen bis zum Gegenvart. By Janheinz Jahn. Düsseldorf-Köln: Eugen Diederichs Verlag, 1965. Pp. xxxv, 360. $D M 42$ ). It is divided into three parts on a geographical basis and contains valuable bibliographical data and notes on each item. An attempt has been made as far as possible to include works written in European and African languages, translations and new editions.

The first part, which deals with Africa, is unfortunately by no means complete, since the author has relied only on direct information from the literary historians without consulting such sources as the Nigerian Publications (Ibadan), the Nigerian national bibliography, or the South African National Bibliography (Pretoria). A careful study of these and other sources such as recently published African literary anthologies and personal communications from African writers, has made it possible to augment this first part of Jahn's bibliography by nearly 30 per cent. This additional material includes new works, recent editions and translations. One part of this supplementary bibliography, by Paul Paricsy, is to be issued in The Journal of New African Literature (Stanford). Among the most interesting additions are: a novel in Zulu, UNomalanga kaNdengezi, by R. R. R. Dhlomo (1964); an English adaptation of Three Yoruba Plays, by Duro Ladipo, by Ulli Beier (1964); a Danish translation of the autobiography of A. J. Luthuli, Let My People Go (1963); a Pedi play by Silpha Phaladi Ngwako Makwala, Kgasane (1962); and Vhamusanda vho-dzegere, a Venda drama by E. S. Netshilema (1960).

(Communicated by Paul Páricsy, Institute of Hungarian Academy of Sciences, Vácrátót)

\section{'The Aboakyer of the Effutu: A Critique of Meyerowitz's Account'}

WE have received the following comments on the paper by Robert W. Wyllie (Africa, xxxvii, I, 1967, pp. 8I- 9 ) from Mrs. Eva L. R. Meyerowitz:

Mr. Robert W. Wyllie claims that there are various inaccuracies in my description of the Aboakyer, published in The Akan of Ghana: Their Ancient Beliefs (1958, pp. 38-42). I did not witness the festival and got my information, in 1946, from the Ex-Omanhene of Winneba, Nana Ayiribi Acquah, in the presence of some elders, but I doubt whether 'inaccuracy' is the right word. Mr. Wyllie makes five points. 